EXPERIMENTAL STUDY

\title{
Expression of Gas proteins and TSH receptor signalling in hyperfunctioning thyroid nodules with TSH receptor mutations
}

\author{
Hans-Peter Holzapfel, Beate Bergner, Peter Wonerow and Ralf Paschke \\ Medical Department III, University of Leipzig, Ph.-Rosenthal-Straße 27, 04103 Leipzig, Germany \\ (Correspondence should be addressed to R Paschke, Medizinische Klinik und Poliklinik III, Universität Leipzig, Ph.-Rosenthal-Straße 27, 04103 Leipzig, \\ Germany; Email: pasr@medizin.uni-leipzig.de)
}

\begin{abstract}
Objective: Constitutively activating mutations of the thyrotrophin receptor (TSHR) are the main molecular cause of hyperfunctioning thyroid nodules (HTNs). The G protein coupling is an important

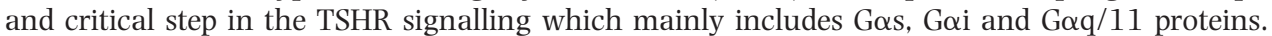

Design: We investigated the in vitro consequences of overexpressing $\mathrm{G} \alpha$ proteins on signalling of the wild-type (WT) or mutated TSHR. Moreover, we investigated whether changes in G $\alpha$ protein expression are pathophysiologically relevant in HTNs or cold thyroid nodules (CTNs).

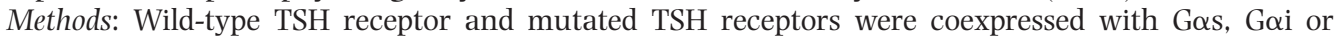
G $\alpha \mathrm{q} / 11$, and cAMP and inositol phosphate (IP) production was measured after stimulation with

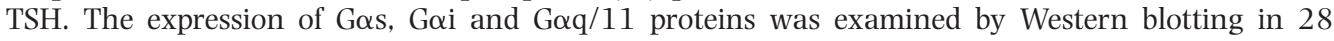
HTNs and 14 CTNs.

Results: Coexpression of G $\alpha$ s with the WT TSH receptor in COS 7 cells significantly increased the basal and TSH-stimulated cAMP accumulation while coexpression of the G $\alpha$ q or G $\alpha 11$ protein significantly increased the production of cAMP and inositol triphosphate $\left(\mathrm{IP}_{3}\right)$. The coexpression of the TSH recep-

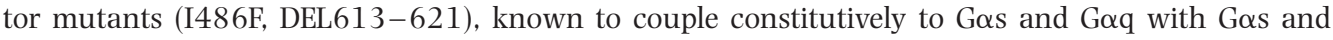
$\mathrm{G} \alpha \mathrm{q} / 11$, significantly increased the basal and stimulated cAMP and $\mathrm{IP}_{3}$ accumulation. Coexpression of the TSH receptor mutant V556F with G $\alpha$ s only increased the basal and stimulated cAMP production while its coexpression with $\mathrm{G} \alpha \mathrm{q} / 11$ increased the basal and stimulated $\mathrm{IP}_{3}$ signalling. The expression of Gos protein subunits determined by Western blotting was significantly decreased in 14 HTNs with a constitutively activating TSH receptor mutation in comparison with the corresponding surrounding tissue, while in 14 HTNs without TSH receptor or Gas protein mutation and in 14 CTNs the expression of Gas protein was not different compared with the surrounding tissue. The

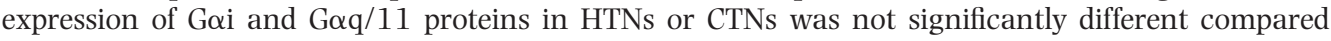
with the surrounding tissue.

Conclusions: The reduced expression of G $\alpha$ s protein subunits in HTNs with TSHR mutations could act as a feedback mechanism to desensitise the chronically stimulated cAMP cascade. As G $\alpha$ protein expression was not significantly increased in the majority of CTNs and HTNs an influence of Ga overexpression on TSH signalling could be excluded in these nodules.
\end{abstract}

European Journal of Endocrinology 147 109-116

\section{Introduction}

The thyrotrophin (TSH) receptor is known to couple to 11 different G protein $\alpha$ subunits in vitro. TSH receptor signalling mainly involves the G protein $\alpha$ subunits Gs, $\mathrm{Gi}$ and $\mathrm{Gq} / 11$ leading to an activation of the cAMP and the phospholipase C (PLC) pathways $(1,2)$. While low concentrations of TSH lead to a sufficient stimulation of cAMP production, up to 100-fold concentrations of TSH are necessary to induce PLC activation (3). The cAMP cascade is the major signal transduction pathway of the TSH receptor (TSHR) in vivo and has been shown to activate mitogenesis and thyroid hormone production (4). Changes in G protein coupling and signal transduction have recently been demonstrated for the TSHR variant $\mathrm{Y} 601 \mathrm{H}$ compared with the wildtype (WT) TSH receptor $(5,6)$. As constitutively activating TSH receptor mutations which frequently occur in hyperfunctioning thyroid nodules (HTNs) cause changes within the intracellular receptor conformation, these mutations could also lead to variations of $\mathrm{G}$ protein coupling and signal transduction (5). This hypothesis is also supported by the variable Gos or Gai protein expression in HTNs (7-10). However, 
it is not known whether the overexpression of the various $\mathrm{G} \alpha$ proteins has any effect on the signal transduction of the WT or mutated TSHR.

Constitutively activating TSH receptor mutations and, with a lower prevalence, mutations of the G $\alpha$ s protein have been shown to be the main molecular causes of HTNs (11-16). However, the relative contribution of constitutive TSHR activation and possible variations of $\mathrm{G}$ protein expression to the clinical phenotype of HTNs has been debated. Induction of Gas expression increases constitutive as well as stimulated cAMP accumulation. Investigations of $\mathrm{G}$ protein expression in HTNs have reported variable results by demonstrating increased, decreased or unchanged Gas protein levels $(7-10)$. However, the molecular aetiology of these HTNs has, for the most part, not been determined. It is therefore not known whether the variable G protein expression reported for HTNs depends on their molecular aetiology.

The aim of our study was, therefore, to investigate the functional consequences for $G$ protein $\alpha$ subunit overexpression on the signal transduction of the WT and mutated TSH receptors in coexpression experiments in $\operatorname{COS} 7$ cells. Moreover, we also determined the expression of $\mathrm{G} \alpha$ subunits in HTNs with different molecular aetiologies and in cold thyroid nodules (CTNs) which also show increased proliferation (8) together with decreased thyroid hormone production.

\section{Materials and methods}

\section{Samples}

Specimens of 28 HTNs, 14 CTNs and adjacent thyroid tissue of consecutive patients undergoing thyroid resection for treatment of their nodular thyroid growth were obtained at surgery. Prerequisites for inclusion in the study were: the identification of a solitary HTN or a CTN as identified by ultrasound, increased or decreased circumscribed technetium uptake by the nodule with suppression of surrounding thyroid tissue on scintiscan (in the case of HTNs), and macroscopic and microscopic identification of the nodule by a pathologist. All patients with HTNs suffered from overt hyperthyroidism with suppressed TSH and elevated thyroid hormones and negative thyroid antibodies. All patients were euthyroid at the time of surgery. Tissue samples were shock-frozen in liquid nitrogen. Extraction of genomic DNA was performed from the HTNs and the surrounding normal tissue with a Qiagen tissue kit (Qiagen, Hilden, Germany), according to the manufacturer's instructions. Somatic TSH receptor mutations in HTNs were previously determined by denaturating gradient gel electrophoresis (DGGE) and subsequent direct sequencing of the positive bands (12).

Membrane preparations were performed in membrane preparation buffer $(40 \mathrm{mmol} / \mathrm{l}$ Tris/HCl, $250 \mathrm{mmol} / \mathrm{l}$ sucrose, $0.1 \mathrm{mmol} / \mathrm{l}$ dithiothreitol,
$0.1 \mathrm{mmol} / \mathrm{l}$ phenylmethylsulphonylfluoride ( $\mathrm{pH}$ 7.4). Tissue samples were homogenised in ice-cold membrane preparation buffer and centrifuged $(700 \mathrm{~g} /$ $10 \mathrm{~min} / 4^{\circ} \mathrm{C}$ ). The supernatant was further centrifuged for $45 \mathrm{~min}$ at $60000 \mathrm{~g}$ at $4{ }^{\circ} \mathrm{C}$. The pellet was resuspended in membrane preparation buffer (membrane fraction) and the supernatant was used as the cytosolic fraction. Protein content was determined by the method of Bradford (17).

The study was approved by the local ethics committee. Informed consent was obtained from all patients before surgery.

\section{Plasmid construction}

G protein constructs were kindly provided by $\mathrm{R} \mathrm{K}$ Sunhara (Southwestern Medical Center, University of Texas, Dallas, USA; G $\alpha$ s), R R Reed (Johns Hopkins University School of Medicine, Baltimore, Maryland, USA; Gai3), and M Strathmann and M I Simon (California Institute of Technology, Pasadena, USA; G $\alpha q$ and $G \alpha 11)$. The coding sequence of G $\alpha$ s was cut by NcoI and HindIII, purified and subsequently subcloned into the EcoRV and HindIII sites of the pcDNA 3.1-Zeo vector (Invitrogen, Groningen, The Netherlands). Goi3 was cut by EcoRI and HindIII and subcloned into corresponding sites of the pcDNA 3.1-Zeo vector. G $\alpha \mathrm{q}$ was cut by NotI and BamHI and also subcloned into pcDNA 3.1-Zeo vector. The coding sequence of G $\alpha 11$ was cut by Bsu15I and XhoI and subcloned into pcDNA 3.1-Zeo by EcoRV and Xhol. All subcloned fragments were confirmed by sequencing.

\section{Cotransfection of TSHR and G proteins and functional characterisation}

Transient expression of the wild-type and mutant TSHR was performed in 12-well plates $\left(1 \times 10^{5} \operatorname{COS} 7\right.$ cells $)$ using $1 \mu \mathrm{g}$ total DNA per well $(0.5 \mu \mathrm{g}$ TSH receptor, $0.5 \mu \mathrm{g}$ G protein) and FuGene6-reagent (Boehringer, Ingelheim, Germany) according to the manufacturer's instructions. Twenty-four hours after transfection the cells were prepared for cAMP assays by washing once with PBS buffer and preincubation for $15 \mathrm{~min}$ with $1 \mathrm{mmol} / \mathrm{l}$ isobutylmethylxanthine (Sigma, Munich, Germany) in serum-free Dulbecco's modified Eagle's medium (DMEM). Thereafter, cells were stimulated with bovine TSH for $1 \mathrm{~h}$ at $37^{\circ} \mathrm{C}$ in the same buffer. The reactions were stopped by aspiration of the medium and addition of $0.1 \mathrm{~mol} / \mathrm{l} \mathrm{HCl}$. Supernatants were collected, dried and resuspended in $200 \mu \mathrm{l}$ Tris/ EDTA buffer $(0.05 \mathrm{~mol} / \mathrm{l}$ Tris, $4 \mathrm{mmol} / \mathrm{l}$ EDTA, pH 7.5). cAMP was assayed using a ${ }^{3} \mathrm{H}$-cAMP RIA kit (Amersham Co., Amersham, Bucks, UK) according to the manufacturer's instructions.

For determination of the TSHR cell surface expression, transfected cells were incubated with antihuman TSHR antibody (2C11, Serotec Ltd, Oxford, 
Oxon, UK; $10 \mu \mathrm{g} / \mathrm{ml}$ in PBS containing $0.1 \%$ BSA). After two washes with PBS $(0.1 \%$ BSA $)$ cells were incubated with the fluorescent conjugated $\mathrm{F}\left(\mathrm{ab}^{\prime}\right) 2$ rabbit anti mouse IgG secondary antibody (Star9B, Serotec Ltd; 1:100 dilution in PBS containing 0.1\% BSA) for $1 \mathrm{~h}$ on ice in the dark. The fluorescence of 10000 cells per tube was assayed by a FACScan Cytofluorometer (Becton Dickinson, Tranklin Lakes, USA).

\section{Stimulation of inositol phosphate formation}

Inositol phosphates were measured as described (18). Forty hours after transfection $2 \times 10^{5} \operatorname{COS} 7$ cells were incubated with $2 \mu \mathrm{Ci} / \mathrm{ml} \quad\left[\right.$ myo- $\left.{ }^{3} \mathrm{H}\right]$ inositol (18.6 Ci/mmol, Amersham Pharmacia Biotech, Amersham, Bucks, UK) for $8 \mathrm{~h}$. Thereafter, cells were preincubated in serum-free DMEM containing $10 \mathrm{mmol} / \mathrm{l} \mathrm{LiCl}$ for $20 \mathrm{~min}$. Subsequently, cells were stimulated with bovine TSH for $1 \mathrm{~h}$ as described before (18). Stimulation was terminated by aspiration of the medium and addition of $0.5 \mathrm{ml} 3 \%$ perchloric acid. TSH-induced increases in intracellular inositol phosphate (IP) levels were determined by anion exchange chromatography. IP values are expressed as the percentage of radioactivity incorporated in inositol phosphates and phosphatidyl inositols.

\section{Western blot analysis}

Equal amounts of protein were added to electrophoresis sample buffer, heated at $95^{\circ} \mathrm{C}$ for $5 \mathrm{~min}$ and electrophoresed $(25 \mu \mathrm{g}$ protein/per lane for COS 7 cells, $6 \mu \mathrm{g} /$ lane for thyroid samples) on a $10 \%$ polyacrylamide gel containing $0.1 \%$ sodium dodecylsulphate using the discontinuous buffer system described by Davis (19). After electrophoresis the proteins were blotted (Semi dry blotter; BioRad, Hercules, CA, USA) onto nitro-cellulose membranes (Schleicher \& Shuell, Dassel, Germany) and after blocking in 5\% non-fat dry milk (NFDM) in Tris-buffered saline/Tween (TBS/T; $20 \mathrm{mmol} / \mathrm{l}$ Tris/HCl, pH 7.6, $150 \mathrm{mmol} / \mathrm{l}$ $\mathrm{NaCl}, 0.1 \%$ Tween 20) ( $1 \mathrm{~h}$, room temperature (RT)) the membranes were probed overnight with $\mathrm{G}$ protein $\alpha$ subunit specific antibodies (Santa Cruz Biotechnology, Santa Cruz, CA, USA) in TBS/T $(20 \mathrm{mmol} / \mathrm{l}$ Tris/HCl, $\mathrm{pH}$ 7.6, $150 \mathrm{mmol} / \mathrm{l} \mathrm{NaCl}, 0.05 \mathrm{mmol} / \mathrm{l}$ Tween 20, $5 \%$ BSA, $0.2 \mu \mathrm{g}$ antibody $/ \mathrm{ml}$ buffer). After washing in PBS/T (3 times, $5 \mathrm{~min}, \mathrm{RT}$ ) the membranes were probed (1 h, RT) with the secondary horseradish peroxidase-conjugated anti-rabbit antibody (1:2000 dilution in PBS/T and 5\% NFDM; New England Biolabs, Beverly, USA) and finally washed 4 times with PBS/T each for $5 \mathrm{~min}$. Following an incubation ( $5 \mathrm{~min}, \mathrm{RT}$ ) with chemiluminescence reagent (SuperSignal; Pierce, Rockford, IL, USA) the proteins were detected using the Chemi Imager 4000 System (Alpha Innotech Corporation, San Leandro, USA).

\section{Data analysis}

G protein expression is given as means \pm S.E.M. of duplicate measurements. IP and cAMP values of cotransfection experiments are given as means \pm S.E.M. of three independent experiments, each performed in duplicate. Statistical analysis was carried out by Student's $t$-test.

\section{Results}

\section{Functional characterisation of TSH receptor and $G$ protein interaction}

To investigate the functional influence of different overexpressed G protein $\alpha$ subunits on TSH receptor signal-

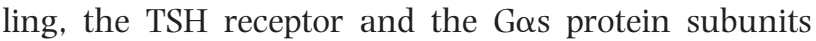
were coexpressed in COS 7 cells and accumulation of cAMP and IP was determined with and without TSH stimulation. A high expression of $\mathrm{G}$ proteins in transfected cells could be demonstrated by Western blotting of COS 7 cells transiently transfected with plasmids containing cDNAs of G $\alpha$ s, i, q and 11 (Fig. 1). Transfection efficiency of the TSH receptor was 30 to $40 \%$ in all experiments as determined by FACS analysis, and surface expression of the receptor was readily detectable at high levels for all transfected TSH receptor constructs. We could not find any difference in the endogenous expression of $\mathrm{G} \alpha$ proteins by transfection of COS 7 cells with the WT TSHR or constitutively activating TSHR mutants. There was no difference in cell surface expression of the constitutively activated TSH receptor mutants Del613-621, I486F and V656F when coexpressed with $\mathrm{G} \alpha \mathrm{s}$, Gi or $\mathrm{Gq} / 11$ protein and stimulated with TSH compared with the coexpression of the TSH receptor mutants DEL613-621, I486F and V656F together with the empty expression vector (data not shown).

The overexpression of Gas protein increased the basal and the TSH-stimulated cAMP accumulation in COS 7 cells transiently cotransfected with the WT TSHR or the constitutively activating TSH receptor mutants DEL613-621, I486F and V656F (Fig. 2). In contrast to $\mathrm{G} \alpha$ s protein, the overexpression of $\mathrm{G} \alpha \mathrm{i}_{3}$ protein significantly decreased the stimulated cAMP accumulation of the coexpressed WT and mutated

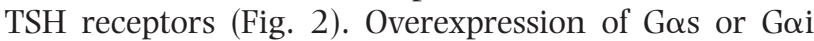
proteins did not significantly affect the basal and TSH-stimulated IP level of the WT TSH receptor (Fig. 3). Moreover, coexpression of $\mathrm{G} \alpha \mathrm{q}$ protein or G $\alpha 11$ protein with the WT TSH receptor or TSH receptor mutants led to a strong increase in basal and stimulated $\mathrm{IP}_{3}$ (Fig. 3).

\section{Expression of G protein a subunits in HTNs and CTNs}

Gas protein content was decreased to $78 \%$ of the corresponding surrounding tissue in HTNs with a somatic 


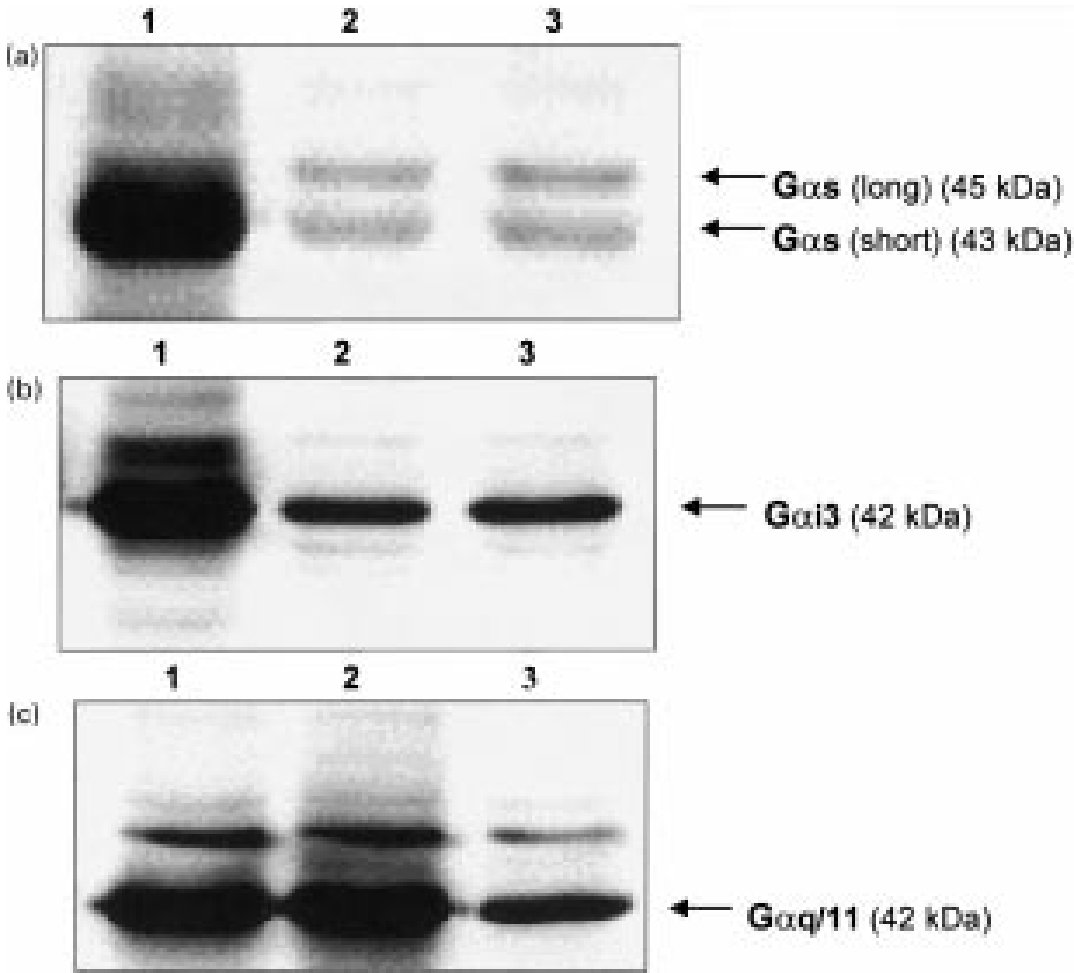

Figure 1 (a) Expression of $\mathrm{G} \alpha \mathrm{s}$ in (1) COS 7 cells cotransfected with WT TSHR and Gos protein, (2) untransfected COS 7 cells and (3) COS 7 cells transfected with WT TSHR and pcDNA3.1-Zeo vector. Cell lysates were electrophoresed on SDS-polyacrylamide gels $(25 \mu \mathrm{g}$ protein per lane), electroblotted and probed with polyclonal rabbit antibodies. (b)Expression of $\mathrm{G \alpha}_{3} \mathrm{i}_{3}$ in (1) COS 7 cells cotransfected with WT TSHR and $\mathrm{G}_{\alpha} \mathrm{i}_{3}$, (2) untransfected COS 7 cells and (3) COS 7 cells transfected with WT TSHR and pcDNA 3.1-Zeo vector. (c) Expression of $\mathrm{G} \alpha \mathrm{q} / 11$ in (1) COS 7 cells cotransfected with WT TSHR and $\mathrm{G} \alpha \mathrm{q},(2) \mathrm{COS} 7$ cells cotransfected with WT TSHR and $\mathrm{G} \alpha 11$ and (3) untransfected COS 7 cells.

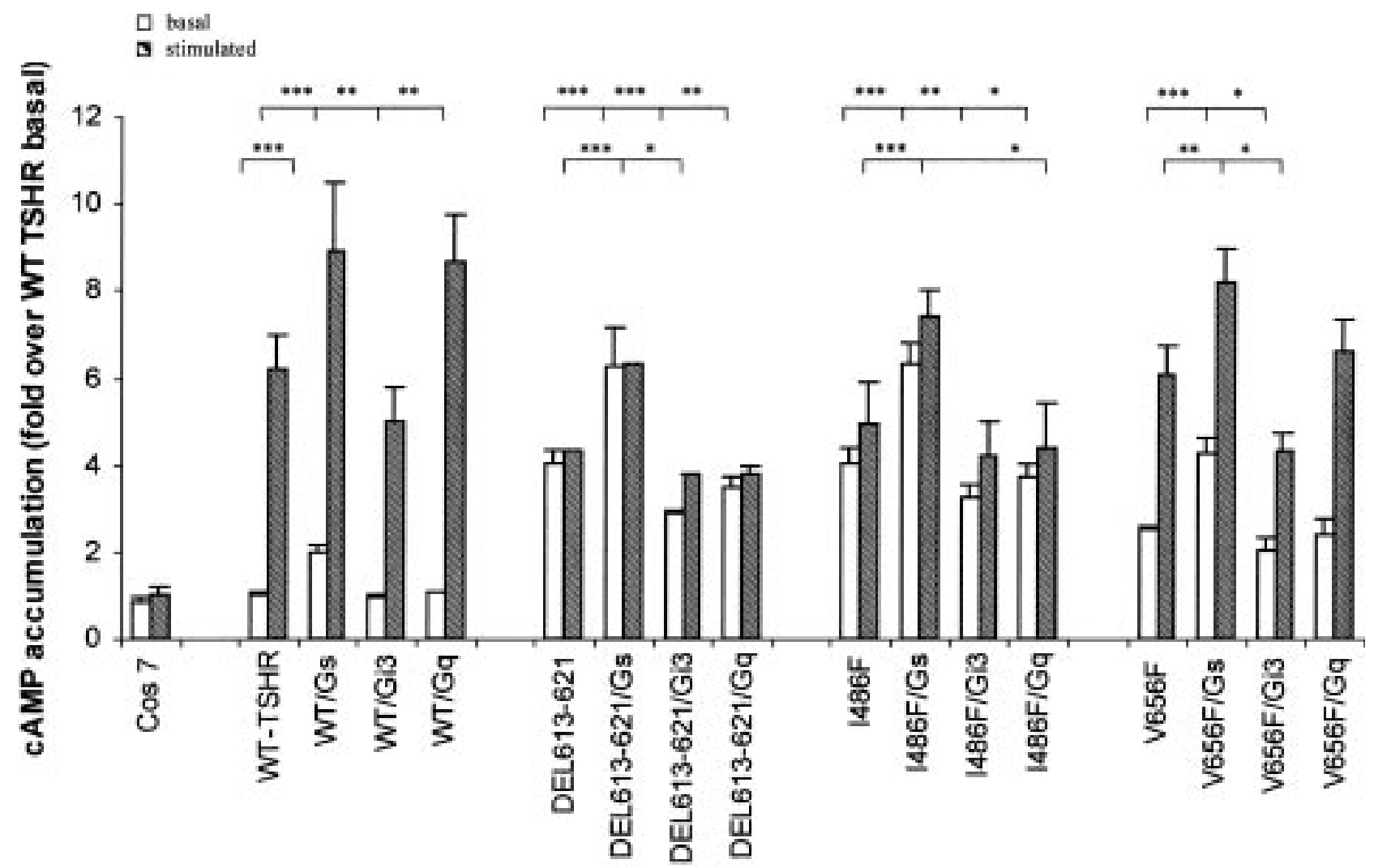

Figure 2 cAMP accumulation in COS 7 cells cotransfected with different TSHR constructs and $\mathrm{G} \alpha$ protein subunits. The basal cAMP accumulation of the WT TSHR was set at 1 and all other data are expressed as fold of the basal cAMP of the WT TSHR. The cells were stimulated with $100 \mathrm{mU} / \mathrm{ml}$ bovine TSH for 1 hour as indicated (hatched bars). Data are given as means \pm S.E.M. of three independent measurements. ${ }^{*} P<0.05 ;{ }^{* *} P<0.01 ;{ }^{* * *} P<0.001$. 


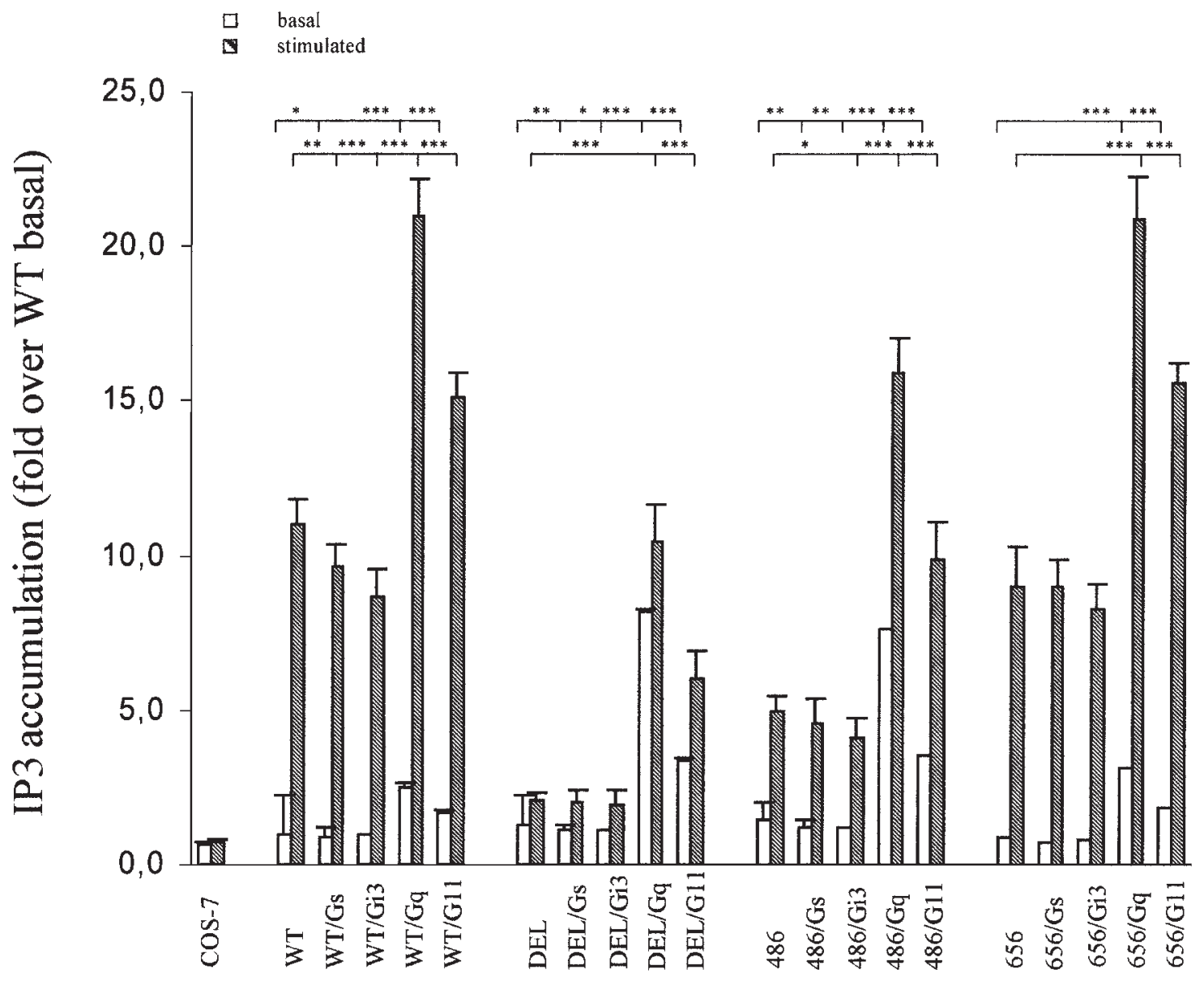

Figure 3 Inositol triphosphate accumulation in COS 7 cells cotransfected with different TSHR constructs and G $\alpha$ protein subunits. The basal IP production of the WT TSHR was set at 1 and all other data are expressed as fold of the basal IP production of the WT TSHR. The cells were stimulated with $100 \mathrm{mU} / \mathrm{ml}$ bovine TSH for 1 hour as indicated. Data are given as means \pm S.E.M. of three independent measurements. ${ }^{\star} P<0.05 ;{ }^{\star \star} P<0.01 ;{ }^{* \star *} P<0.001$.

constitutively activating TSH mutation (14 cases) compared with their corresponding surrounding tissues, while no significant differences in the expression of Gas protein could be found between CTNs (14 cases) and their corresponding surrounding tissues (Figs. 4 and 5). More than 50\% of the HTNs showed a decreased G $\alpha$ s protein expression. In contrast to HTNs with a somatic TSH receptor mutation there was no significant decrease of G $\alpha$ s protein expression in HTNs without a TSH receptor or G $\alpha$ s protein mutation (14 cases) (Fig. 4). G $\alpha$ i protein expression was not significantly changed in either HTNs or CTNs compared with their surrounding tissues. This was also true for

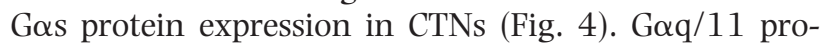
tein content was unchanged in CTNs and HTNs compared with their corresponding surrounding tissues (Fig. 4). The data in our patient population followed a Gaussian distribution (normality test passed), and no separate populations could be discerned. Despite the range of standard deviations no further statistical tests were performed.

\section{Discussion}

Our results showing an increased cAMP accumulation by coexpression of constitutively activating mutations of the TSHR with G $\alpha$ s subunits are in agreement with data showing that an overexpression of Gos protein increases the constitutive as well as the stimulated cAMP accumulation and the transcriptional activation of cAMP-dependent reporter genes (20). The decreased TSH-stimulated accumulation of cAMP by coexpression of Gai together with the TSHR is most likely due to the known inhibitory potential of the overexpressed Goi protein subunits on adenylylcyclase activity (21). TSHR coupling to Gai subunits has been found in in vitro experiments and has previously been described as functionally relevant in vivo $(1,2)$. Coexpression of Goi with mutated TSHR showed an inhibition of stimulated cAMP and IP (in the case of I486F) indicating the

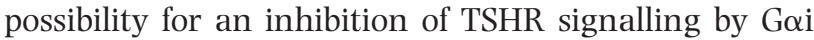
overexpression. Overexpression of $\mathrm{G} \alpha \mathrm{q}$ protein or G $\alpha 11$ protein subunits also led to an increase in basal 

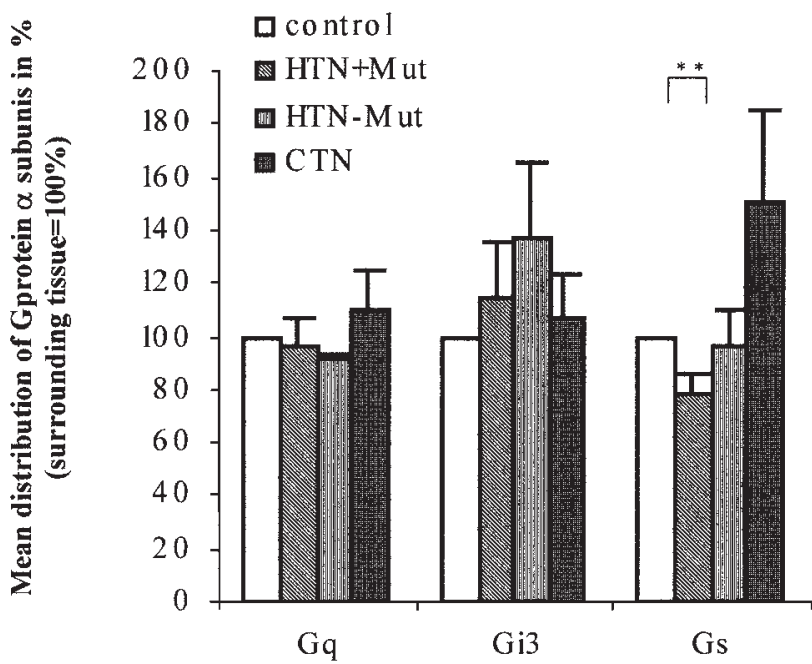

Figure 4 Expression of membrane bound G proteins quantified by Western blotting in toxic thyroid nodules with TSH receptor mutations (HTN + Mut), hyperfunctioning thyroid nodules without TSH receptor mutations (HTN - Mut), and cold thyroid nodules (CTN), each compared with their corresponding surrounding tissue set at $100 \%$ (open bars) quantified by Western blotting. Data are means \pm S.E.M. of duplicate measurements. ${ }^{* \star} P<0.01$.

and stimulated IP accumulation in COS 7 cells when coexpressed with the WT TSH receptor or the TSH receptor mutants. The IP accumulation was not related to the constitutive activity of the TSH receptor mutants. Therefore, increased G $\alpha \mathrm{q} / 11$ protein expression in vitro can lead to an increased TSHR-PLC signalling. Results from in vitro experiments often differ from in vivo situations. These differences can be caused by the use of artificial promoters, heterologous cell systems and transient transfections in the in vitro experiments. Therefore, the results of our in vitro experiments should be handled with caution when used to analyse the in vivo situation in HTNs.

To investigate the relevance of our in vitro coexpression data in vivo the expression of $\mathrm{G} \alpha$ proteins in HTNs and CTNs was determined by Western blotting. Reduced expression of Gos proteins in HTNs (9), increased G $\alpha$ s protein expression $(7,8)$ or no change in Gos protein expression (10) in HTNs have recently been reported. The samples examined in former studies of $\mathrm{G} \alpha$ s protein expression, except those described by Derwahl et al. (7), were not analysed for mutations in the TSHR or in the Gas protein $(8,10,22,23)$ or have only been screened for G $\alpha$ s protein mutations (22). Some investigators used, in addition to Western blotting, ADP ribosylation experiments to investigate $\mathrm{G}$ protein expression (7-9). A further aspect reducing the strength of the former results is the low number of HTNs investigated, 2 (23), 7 (9), 4 (8), 10 (7) and

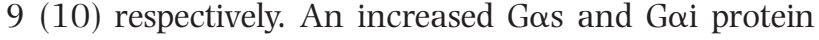
content in 5 HTNs with and 5 HTNs without TSHR or Gs $\alpha$ protein mutation has recently been reported (7). Our results of decreased expression of Gos in HTNs with TSHR mutations are difficult to reconcile with this report by Derwahl and co-workers. We and others (8) have shown that both G $\alpha$ protein and cAMP content in thyroid tumours varies greatly. However, the HTNs included in our study were screened for TSH receptor mutations and mutations in the Gos protein gene by DNA sequencing and DGGE $(12,16,24)$ and were also examined for their clonality (25). In $58 \%$ of the HTNs somatic TSHR or G $\alpha$ s protein mutations were identified, making a constitutive activation of the cAMP pathway in these HTNs very likely (12). However, $42 \%$ of the HTNs were negative for TSHR or G $\alpha$ s protein mutations even with the sensitive DGGE method (12, $16,24)$, which indicates that in HTNs without TSHR mutation different growth stimulating mechanisms bypassing the TSHR are likely to exist. Therefore, the molecular cause and the activated signalling cascade in these HTNs are currently not known, which makes them unsuitable candidates for studies trying to elucidate the in vivo consequences of chronic cAMP activation on the pattern of $\mathrm{G} \alpha$ protein subunit expression. Therefore, our clinical and molecular characterisation allows us to relate the expression of $\mathrm{G} \alpha$ subunits to defined clinical entities such as HTNs with TSHR mutations compared with HTNs without TSHR or G $\alpha$ s mutations and with CTNs.

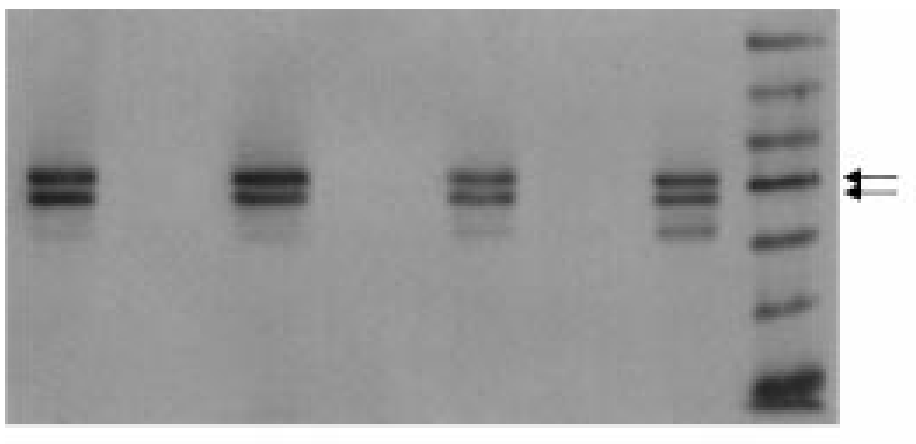

Ges $45 \mathrm{kDa}$ Geas $43 \mathrm{kDa}$

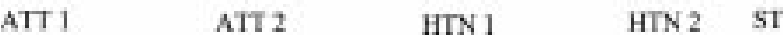

Figure 5 Expression of $\mathrm{G} \alpha$ s proteins in two representive hyperfunctioning thyroid nodules with TSH receptor mutation (HTN1 and 2) and the corresponding adjacent thyroid tissue (ATT1 and 2). Cell lysates were electrophoresed on SDS-polyacrylamide gels $(25 \mu \mathrm{g}$ protein per lane), electroblotted and probed with a polyclonal rabbit antibody. ST, standard protein marker. 
G $\alpha$ s protein degradation is increased after stimulation of the cAMP cascade (26) and the activity of the G $\alpha$ s protein correlates well with the amount of protein (20). Therefore, the chronically activated cAMP pathway in HTNs harbouring constitutively activating TSHR mutations (11) could induce a higher degradation of $\mathrm{G} \alpha \mathrm{s}$ proteins leading very probably to a reduced activity of the G $\alpha$ s protein pathway in these HTNs. The decreased G $\alpha$ s protein content in TSHR mutation positive samples is most likely a cellular feedback mechanism to the chronic stimulation of the cAMP cascade. A feedback mechanism by a specific phosphodiesterase activation reducing the increased cAMP production in HTNs with TSH and Gos protein mutations has recently been described (27). Both mechanisms, which are not sufficient to prevent tumour development, may exist in parallel and may reduce the constitutively produced cAMP in HTNs with TSHR or G $\alpha$ s protein mutations.

However, Gas protein content has been shown to be increased after $18 \mathrm{~h}$ of TSH stimulation of thyroid follicular cells in vitro (28) while an increased degradation of $\mathrm{G} \alpha \mathrm{s}$ protein has been shown after stimulation of the cAMP cascade (26). Differences between expression data from in vivo and in vitro conditions demonstrated by primary thyroid cells and HTNs $(29,30)$ most likely result from unknown adaptation processes during chronic stimulation in an intact cell system in vivo (28). A decreased Gos protein content in lung tissue of rats chronically treated with albuterol has recently been described (31) as the molecular aetiology for the heterologous desensitisation of pulmonary Gas-coupled receptors. Therefore, the chronic stimulation of the cAMP system caused by constitutively activating mutations of TSHR in most of the HTNs could similarly desensitise the cAMP pathway by decreasing the $\mathrm{G} \alpha$ s protein expression.

An increased Goi protein expression in HTNs not investigated for TSHR mutations (10) and in both HTNs with and without TSHR or G $\alpha$ s mutations (7) has been reported. We only found an overexpression of Gai proteins in 5 out of 28 thyroid HTNs compared with their corresponding surrounding tissue that could have increased the inhibition of the adenylylcyclase activity in these HTNs. The differences between our study, the study by Selzer et al. (10) and the study of Derwahl and co-workers (7) may result from different detection systems, the use of different antibodies, and the different selection and characterisation of the

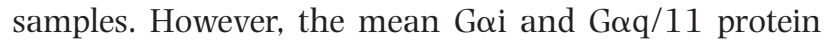
expression in our HTNs and CTNs as well as the Gos protein expression in our CTNs was not different compared with their surrounding tissue. Similar results have previously been reported for CTNs (8). Therefore,

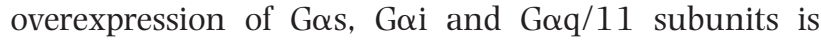
unlikely to mediate the increased mitogenic signalling in HTNs or CTNs.

In conclusion, the reduced Gas protein expression in HTNs with a TSH receptor mutation is most likely induced by a feedback mechanism which desensitises the constitutively activated cAMP cascade in HTNs harbouring a constitutively activating TSH receptor mutation. In vitro overexpression of $\mathrm{G} \alpha$ s protein and $\mathrm{G} \alpha \mathrm{q} / 11$ protein results in an increase of the basal and activated cAMP and $\mathrm{IP}_{3}$ signalling of the WT TSH receptor or TSH receptor mutants. While the in

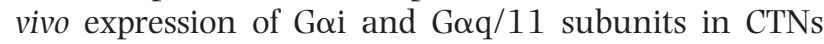
or HTNs varies greatly the influence of $\mathrm{G} \alpha \mathrm{q} / 11$ or Goi subunit overexpression on TSH receptor signalling could contribute to nodular growth in some HTNs or CTNs.

\section{Acknowledgements}

We thank R K Sunhara (Southwestern Medical Center, University of Texas, Dallas) for the Gas construct, R R Reed (John Hopkins University School of Medicine, Baltimore, Maryland) for the $\mathrm{G} \alpha \mathrm{i}_{3}$ construct and $\mathrm{M}$ Strathmann and M I Simon (California Institute of Technology, Pasadena) for providing the G $\alpha q$ and G $\alpha 11$ constructs. This study was supported by grants from the Deutsche Forschungsgemeinschaft (Ho 1764/4-1) and from the BMBF Interdisciplinary Centre for Clinical Research at the University of Leipzig (01 KS 9504, project B 14).

\section{References}

1 Allgeier A, Laugwitz KL, Van Sande J, Schultz G \& Dumont JE. Multiple G-protein coupling of the dog thyrotropin receptor. Molecular and Cellular Endocrinology 1997127 81-90.

2 Laugwitz KL, Allgeier A, Offermanns S, Spicher K, Van Sande J, Dumont JE et al. The human thyrotropin receptor: a heptahelical receptor capable of stimulating members of all four $\mathrm{G}$ protein families. PNAS 199693 116-120.

3 Van Sande J, Parma J, Tonacchera M, Swillens S, Dumont J \& Vassart G. Genetic basis of endocrine disease: somatic and germline mutations of the thyrotropin receptor in thyroid diseases. Journal of Clinical Endocrinology and Metabolism 1995802577 2585.

4 Dumont JE, Jauniaux J-C \& Roger PP. The cyclic AMP-mediated stimulation of cell proliferation. Trends in Biological Sciences $19891467-71$.

5 Arseven OK, Wilkes WP, Jameson JL \& Kopp P. Substitutions of tyrosine 601 in the human thyrotropin receptor result in increase or loss of basal activation of the cyclic adenosine monophosphate pathway and disrupt coupling to Gq/11. Thyroid $2000103-10$.

6 Biebermann H, Schöneberg T, Schulz A, Krause G, Grüters A, Schultz G et al. A conserved tyrosine residue (Y601) in transmembrane domain 5 of the thyrotropin receptor serves as a molecular switch to determine G-protein coupling. FASEB Journal 199812 1461-1471.

7 Derwahl M, Hamacher C, Russo D, Broecker M, Manole D, Schatz $\mathrm{H}$ et al. Constitutive activation of the Gs alpha protein-adenylate cyclase pathway may not be sufficient to generate toxic thyroid adenomas. Journal of Clinical Endocrinology and Metabolism 1996 81 1898-1904.

8 Hamacher C, Studer H, Zbaeren J, Schatz H \& Derwahl M. Expression of functional stimulatory guanine nucleotide binding protein in nonfunctioning thyroid adenomas is not correlated to adenylate cyclase activity and growth of these tumors. Journal of Clinical Endocrinology and Metabolism $1995801724-1732$. 
9 Delemer B, Dib K, Patey M, Jacquemin C \& Corrèze C. Modification of the amounts of $\mathrm{G}$ proteins and of the activity of adenylyl cyclase in human benign thyroid tumours. Journal of Endocrinology 1992 $132477-485$.

10 Selzer E, Wilfing A, Schiferer A, Hermann M, Grubeck-Loebenstein B \& Freissmuth M. Stimulation of human thyroid growth via the inhibitory guanine nucleotide binding $(G)$ protein Gi: constitutive expression of the G-protein alpha subunit Gi alpha-1 in autonomous adenoma. PNAS 199390 1609-1613.

11 Paschke R \& Ludgate M. The thyrotropin receptor in thyroid diseases. New England Journal of Medicine 1997337 1675-1681.

12 Trultzsch B, Krohn K, Wonerow P, Chey S, Holzapfel H-P, Ackermann F et al. Detection of thyroid-stimulating hormone receptor and Gs $\alpha$ mutations in 75 toxic thyroid nodules by denaturing gradient gel electrophoresis. Journal of Molecular Medicine 200178 684-691.

13 Parma J, Duprez L, Van Sande J, Cochaux P, Gervy C, Mockel J et al. Somatic mutations in the thyrotropin receptor gene cause hyperfunctioning thyroid adenomas. Nature $1993 \mathbf{3 6 5} 649-651$.

14 Parma J, Duprez L, Van Sande J, Hermans J, Rocmans P, Van Vliet $\mathrm{G}$ et al. Diversity and prevalence of somatic mutations in the thyrotropin receptor and Gs alpha genes as cause of toxic thyroid adenomas. Journal of Clinical Endocrinology and Metabolism 1997 82 2695-2701.

15 Führer D, Holzapfel H-P, Wonerow P, Scherbaum WA \& Paschke R. Somatic mutations in the thyrotropin receptor gene and not in the Gs alpha protein gene in 31 toxic thyroid nodules. Journal of Clinical Endocrinology and Metabolism 199782 3885-3891.

16 Voigt C, Holzapfel H \& Paschke R. Expression of beta-arrestins in toxic and cold thyroid nodules. FEBS Letters $2000 \mathbf{4 8 6}$ 208-212.

17 Bradford MM. A rapid and sensitive method for the quantitation of microgram quantities of protein utilizing the principle of protein-dye binding. Analytical Biochemistry 197672 248-254.

18 Wonerow P, Chey S, Fuhrer D, Holzapfel HP \& Paschke R. Functional characterization of five constitutively activating thyrotrophin receptor mutations. Clinical Endocrinology $2000 \mathbf{5 3}$ $461-468$.

19 Davis BJ. Disc electrophoresis. II. Method and application to human serum proteins. Annals of the New York Academy of Sciences $1964121241-246$.

20 Yang X, Lee FYG \& Wand GS. Increased expression of $\mathrm{G}_{\mathrm{s}} \alpha$ enhances activation of the adenylyl cyclase signal transduction cascade. Molecular Endocrinology 199711 1053-1061.
21 Lowndes JM, Gupta SK, Osawa S \& Johnson GL. GTPase-deficient $\mathrm{G}$ alpha i2 oncogene gip2 inhibits adenylylcyclase and attenuates receptor-stimulated phospholipase A2 activity. Journal of Biological Chemistry 1991266 14193-14197.

22 Gorelov VN, Dumon K, Barteneva NS, Palm D, Roher HD \& Goretzki PE. Overexpression of Gs alpha subunit in thyroid tumors bearing a mutated Gs alpha gene. Journal of Cancer Research and Clinical Oncology 1995121 219-224.

23 Siperstein AE, Miller RA, Landis C, Bourne HR \& Clarke OH. Increased stimulatory $\mathrm{G}$ protein in neoplastic human thyroid tissues. Surgery $1991110949-955$.

24 Trulzsch B, Krohn K, Wonerow P \& Paschke R. DGGE is more sensitive for the detection of somatic point mutations than direct sequencing. BioTechniques 199927 266-268.

25 Krohn K, Führer D, Holzapfel H-P \& Paschke R. Clonal origin of toxic thyroid nodules with constitutively activating TSH receptor mutations. Journal of Clinical Endocrinology and Metabolism 1998 83 130-134.

26 Levis MJ \& Bourne HR. Activation of the $\alpha$ subunit of $\mathrm{G}_{\mathrm{s}}$ in intact cells alters its abundance, rate of degradation, and membrane avidity. Journal of Biological Chemistry 1992119 1297-1307.

27 Persani L, Lania A, Alberti L, Romoli R, Mantovani G, Filetti S et al. Induction of specific phosphodiesterase isoforms by constitutive activation of the cAMP pathway in autonomous thyroid adenomas. Journal of Clinical Endocrinology and Metabolism $2000 \mathbf{8 5}$ $2872-2878$.

28 Saunier B, Dib K, Delemer B, Jacquemin C \& Corrèze C. Cyclic AMP regulation of Gs protein. Journal of Biological Chemistry $199026519942-19946$.

29 Deleu S, Pirson I, Clermont F, Nakamura T, Dumont JE \& Maenhaut C. Immediate early gene expression in dog thyrocytes in response to growth, proliferation, and differentiation stimuli. Journal of Cell Physiology 1999181 342-354.

30 Deleu S, Allory Y, Radulescu A, Pirson I, Carrasco N, Corvilain B et al. Characterization of autonomous thyroid adenoma: metabolism, gene expression, and pathology. Thyroid $200010131-140$.

31 Finney PA, Belvisi MG, Donnelly LE, Chuang TT, Mak JC, Scorer C et al. Albuterol-induced downregulation of Gs alpha accounts for pulmonary beta(2)-adrenoceptor desensitization in vivo. Journal of Clinical Investigation $2000 \mathbf{1 0 6} 125-135$.

Received 4 October 2001

Accepted 12 March 2002 